\title{
Export Structure Effect of Outward FDI of Sichuan Province of China
}

\author{
Xiaohui Wang ${ }^{1}$ \\ ${ }^{1}$ School of Economics and Management, LeShan Normal University, LeShan, China \\ Correspondence: Xiaohui Wang, School of Economics and Management, LeShan Normal University, No. 402, \\ Unit 2, JinLin, ManTingFang, No. 776, Xiaoba Road, LeShan City, Sichuan Province, China. E-mail: \\ scsnwxh@qq.com
}

Received: August 14, 2018

Accepted: August 30, 2018

Online Published: August 31, 2018

doi:10.5539/ijef.v10n9p181

URL: https://doi.org/10.5539/ijef.v10n9p181

\begin{abstract}
This paper made an export structure effect analysis of outward foreign direct investment of Sichuan Province of China using the method of OLS and GMM with the provincial panel data of ordinary export from 2004 to 2016. The empirical results indicate that Outward Foreign Direct Investment can affect ordinary export positively both in China and in Sichuan Province. With each 1\% increase of outward foreign direct investment, China's ordinary exports increased by $0.344 \%$, while Sichuan's ordinary exports increased by $0.483 \%$. Furthermore, this paper indicates that outward foreign direct investment leads to the upgrading of export structure in China. But, this paper can't find sufficient evidence that Sichuan's Outward Foreign Direct Investment can promote export structure.
\end{abstract}

Keywords: export structure, outward foreign direct investment, OLS, SGMM

\section{Introduction}

Export structure refers to the proportion of various categories of export commodities in total export in a country or region in a certain period of time. Among all the export structure indicators, the export of ordinary trade can reflect the level of foreign trade and economic development and the international competitiveness of products. In the early stage of China's Reform and Development, the export of processing trade, as a major part of China's export, played a significant role in China's foreign trade and economic development. Meanwhile, with the rapid development of processing trade export, its disadvantages of low value-added rate, low technology, high energy consumption and high pollution are more and more obvious. On the other hand, some scholars believe that ordinary trade has a greater technical spillover on the local economy than processing trade (Jarreau \& Poncet, 2012; Yu, 2015). With the development of China's foreign trade, China's ordinary trade export maintained a high growth rate, but it did not surpass the processing trade export until 2011. Ordinary trade exports in Sichuan Province rose from $\$ 3.07$ billion in 2004 to $\$ 10.89$ billion in 2016, up 3.55 times, with an average annual growth rate of 11 percent. The rapid growth of ordinary trade exports has played a great role in promoting China's and also Sichuan's economic growth, so the reasons of the rapid growth of ordinary trade exports are worth further study.

As China's most important strategy, "The Belt And Road" pursues win-win cooperation for common development and common prosperity. Besides the exchange of commodity resources, the greater achievement of "The Belt And Road" is the activation of the economy of all countries. Therefore, China will build array of interconnection projects through expanding Outward Foreign Direct Investment (Hereinafter, OFDI) and encouraging transferring competitive industries to the countries along the Belt and Road. According to the Statistical Bulletin of China's Outward Foreign Direct Investment of 2016, China's OFDI reaches $\$ 181.23134$ billion and Sichuan Province's OFDI reaches $\$ 5.84727$ billion. In 2016, China's OFDI has exceeded the foreign investment it has attracted, which implies that China has shifted to a net exporter of capital from a net importer of capital.

A company has two important ways to enter the global market: OFDI and export. OFDI signifies that the parent company establishes an enterprise in host country and sells products locally or exports to a third country. The subsidiary enterprise in the host country can use global high quality resources and avoid trade barriers. Thus, it can carry out production and management with the advantages of high efficiency and low cost, and then can win the relative advantages over export. On the other hand, OFDI can also promote the export of intermediate inputs 
such as domestic parts and components of home country. Then, how will OFDI influence export of home country and how will OFDI influence the ordinary export and export structure of home country? The conclusions of theoretical researches and practical researches are not unified.

This paper tries to analysis the export structure effect of OFDI of Sichuan Province of China using OLS method and generalized method of moment based on the provincial panel data of ordinary export from 2004 to 2016, and then put forward the proposal for the development of OFDI of Sichuan Province.

\section{Literature Review}

The theoretical research on the relationship between OFDI and international trade started from Mundell (1957). New classic theory holds that the movement of OFDI relies on the differences in factor prices and factor endowments between countries. With international factors becoming mobile, these differences become smaller. Therefore, Mundell (1957) concludes that capital mobility driven by OFDI constitutes a perfect substitute for exports. The international production eclectic theory proposed by Dunning (1977) takes a similar view that OFDI will replace domestic exports. While competitive advantage theory and new trade theory hold that there is a complementary relationship between OFDI and domestic exports, and the global production division will accelerate the pace of international investment of multinational companies, thus promote the growth of international trade. Subsequently, many scholars analyze different relationships between OFDI and trade based on different motivations of OFDI (market seeking, resource and asset seeking and efficiency seeking, etc.) and different types of OFDI (vertical OFDI and horizontal OFDI). They found that resource and asset seeking OFDI and vertical OFDI promote the upgrading of domestic industrial structure through overseas market expansion and reverse technology spillover, and promote the export of intermediate goods in capital-intensive and technology-intensive industries (Helpman, 1984; Lipsey, 2002). They also found that there is a substitution relationship between market seeking and horizontal OFDI and export (Markusen, 1984; Markusen \& Venable, 1995).

Although different empirical research methods are adopted, many empirical scholars believe that there is a complementary relationship between OFDI and export. The national level study of clausing (2000) about American's international corporations in 29 countries from 1977 to 1994 found that OFDI could affect export positively and the positive effect became more obvious when the research took transnational activities and trades inside corporation into consideration. As to industry-level, the research of Marchant et al. (2002) about American food industry's investment in Free Trade Area of America came to the conclusion that OFDI could promote export. As to the level of enterprise, Lipsey and Weiss (1984) found a great positive effect of OFDI on export through their research on the relationship between OFDI in host country and America's export to host country in 1970, and their analysis indicated that there will be an increase of 9 to 25 cents' export of the home country because of one dollar's investment in host country.

China's scholar's research on the relationship between OFDI and export is relatively late, and most of the studies are empirical in the macro level. Benwu (2009) discovered that China's OFDI had an obvious positive affect on exports to host countries through his empirical research based on the panel data of China's OFDI and exports to 50 countries or districts from 2000 to 2006 with gravity model. Chunping (2012) also believed that there is a complementary relationship between OFDI and export through her empirical study. In the micro level, through researching the influence of 1498 enterprise' OFDI to export using the method of data matching and the estimation of difference-in-differences, Guanhong (2014) concluded that OFDI from China's enterprises enlarge exports. He found that OFDI can deepen the intensive margin of exports and can expand the extensive margin of exports. Further more, Yuyu (2012) discovered that OFDI has a positive affect on the trade structure through her study of China's OFDI's influence on the structure of trade using both time series model and panel data model. Jun-cong and Fan-hua (2014) made an empirical research on the relationship between OFDI and export commodity structure by applying Gravity Model based on export trade panel data of China's OFDI with 40 countries during 2003-2011 and the results indicate that OFDI has a positive effect on promoting China's export structure and OFDI significantly promotes China's export of machinery and equipment, spare parts and other intermediate products, both for developed and developing countries.

From what has been discussed above, scholars from outside China focused on the studies on developed countries and usually found a complementary relationship between OFDI and export. Meanwhile, researches of China's scholars usually analyze the impact of China's OFDI on trade from the perspective of national level, rarely from the perspective of region level. Actually, every province of China has a different level of economic development and different natural endowment from each other. Therefor, there may be a unique effect of OFDI on export and export structure for all provinces of China. Thus, this paper attempts to analysis the impact of OFDI on export 
structure of Sichuan Province, using the method of OLS and GMM with provincial ordinary export data from 2004 to 2016, and then put forward the proposal for the development of OFDI of Sichuan province.

\section{Research Design}

\subsection{Theoretical Analysis}

The trade effect of OFDI is closely related to investment motivation. According to different motivations, China's OFDI mainly includes market seeking OFDI, resource and asset seeking OFDI and efficiency seeking OFDI. The following is a brief theoretical analysis of the influence of China's OFDI on export structure in combination with the motivation of OFDI.

Market seeding OFDI may replace exports of final products of home country to host country. Meanwhile, the establishment of factories and the production process may drive the exports of intermediate products such as production equipment and spare parts in home country, which is conducive to the cultivation of emerging industries and may lead to the upgrading of export structure.

Resource and asset seeking OFDI is mainly an investment behavior for acquiring resource of energy and mines, advanced production factors such as advanced technology, technical equipment and brand in host country. Generally speaking, this type of OFDI will lead to the import of scarce resources, high-tech products and related patented technologies, which can quickly promote the upgrading of industrial institutions and promote the upgrading of foreign trade structure of home country.

Efficiency seeking OFDI refers to the relocation of home enterprises to countries or regions where labor and land resources are cheaper when production cost of home country rises to the level in which home enterprises no longer have cost competitive advantage. Most of efficiency seeking OFDI are from industries with excess capacity or "marginal industries" with the lose of comparative advantages. This kind of OFDI can improve the allocation efficiency of domestic production factors in home country, promote emerging industries and make every effort to develop industries with comparative advantages to improve the structure of foreign trade.

\subsection{Model Specification}

One country's export is greatly influenced by its economic development level and resource endowment, which can be reflected by per capita GDP. Therefore, this paper employed the model of panal data as follows:

$$
\begin{gathered}
\ln O E X P_{i t}=\beta_{0}+\beta_{1} \ln O F D I_{i(t-1)}+\beta_{2} \ln P G D P_{i t}+\varepsilon_{i t} \\
\ln E X P_{i t}=\beta_{0}+\beta_{1} \ln O F D I_{i(t-1)}+\beta_{2} \ln P G D P_{i t}+\varepsilon_{i t}
\end{gathered}
$$

Where $O E X P_{i t}$ means the amount of ordinary exports from $i$ district of China in $t$ year, $E X P_{i t}$ means the amount of merchandise exports from $i$ district of China in $t$ year, $O F D I_{i(t-1)}$ means the flow of OFDI from $i$ district of China in $t-1$ year, $P G D P_{i t}$ means per capita Gross Domestic Production of $i$ district of China in $t$ year, $\varepsilon_{i t}$ means the random disturbance term. We adopted logarithmic model, so that the parameters will become the elastic coefficient of the independent variables to the dependent variables, and the square deviation of the logarithmic model can be small. We can determine whether and how OFDI will affect the export structure by comparing the elastic coefficient of OFDI's impact on export and ordinary export in the two models. If the influence coefficient of OFDI on ordinary export is greater than that on export, it indicates that OFDI can improve export structure.

\subsection{Data and Descriptive Statistics}

The data of this paper is panel data of value of export and ordinary export, per capita GDP and the flow of OFDI from 27 provinces of China from 2004 to 2016. The data of PGDP and the amount of export and ordinary export comes from the statistic yearbook of National Bureau of Statistics of China and 27 provinces. The data of flow of OFDI comes from Statistical Bulletin of China's Outward Foreign Direct Investment of 2016. The main description of the variable is shown in table 1. 
Table 1. Variable descriptive statistics

\begin{tabular}{|c|c|c|c|c|c|c|}
\hline variable & & Mean & Std.Dev. & Min & Max & Observations \\
\hline \multirow{3}{*}{ logoexport } & overall & 13.77389 & 1.521302 & 9.798127 & 17.13358 & $\mathrm{~N}=351$ \\
\hline & between & & 1.424664 & 10.85426 & 16.40873 & $n=27$ \\
\hline & within & & .5952161 & 11.99512 & 15.18306 & $\mathrm{~T}=13$ \\
\hline \multirow{3}{*}{ logexport } & overall & 14.31452 & 1.68439 & 10.13412 & 17.98386 & $\mathrm{~N}=351$ \\
\hline & between & & 1.590355 & 11.01508 & 17.57232 & $\mathrm{n}=27$ \\
\hline & within & & .6282172 & 12.59516 & 16.00712 & $\mathrm{~T}=13$ \\
\hline \multirow{3}{*}{ L.Logofdi } & overall & 9.571929 & 2.439762 & 0 & 14.65634 & $\mathrm{~N}=324$ \\
\hline & between & & 1.646596 & 5.176064 & 12.04302 & $\mathrm{n}=27$ \\
\hline & within & & 1.825786 & 4.063211 & 14.33929 & $\mathrm{~T}=12$ \\
\hline \multirow{3}{*}{ Logpgdp } & overall & 8.319565 & .7559579 & 6.257668 & 9.786673 & $\mathrm{~N}=351$ \\
\hline & between & & .4726019 & 7.529843 & 9.285721 & $\mathrm{n}=27$ \\
\hline & within & & .5964709 & 7.047389 & 9.307914 & $\mathrm{~T}=13$ \\
\hline
\end{tabular}

For the preliminary understanding of the relationship between the variables, a scatter plot of logarithm of ordinary export and logarithm of OFDI is draw as figure 1, and also a scatter plot of logarithm of export and logarithm of OFDI is draw as figure 2. From figure 1 and figure 2, we can conclude that there is an obvious positive relationship both between OFDI and ordinary export and between OFDI and export. Thus, we believe that OFDI may promote export and ordinary export. Meanwhile, the export structure effect of OFDI needs further research.

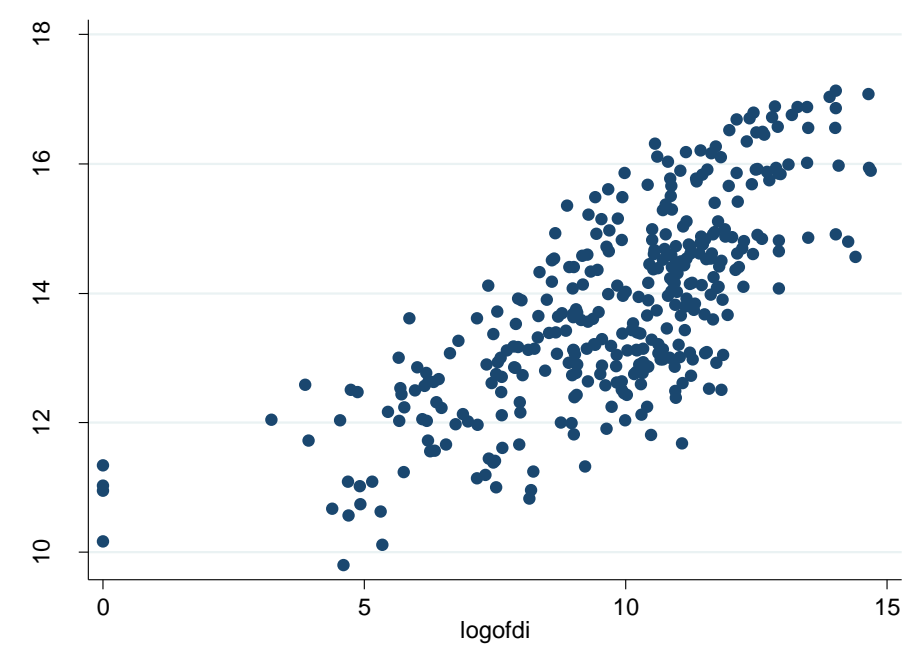

Figure 1. Scatter plot of China's ordinary export and OFDI

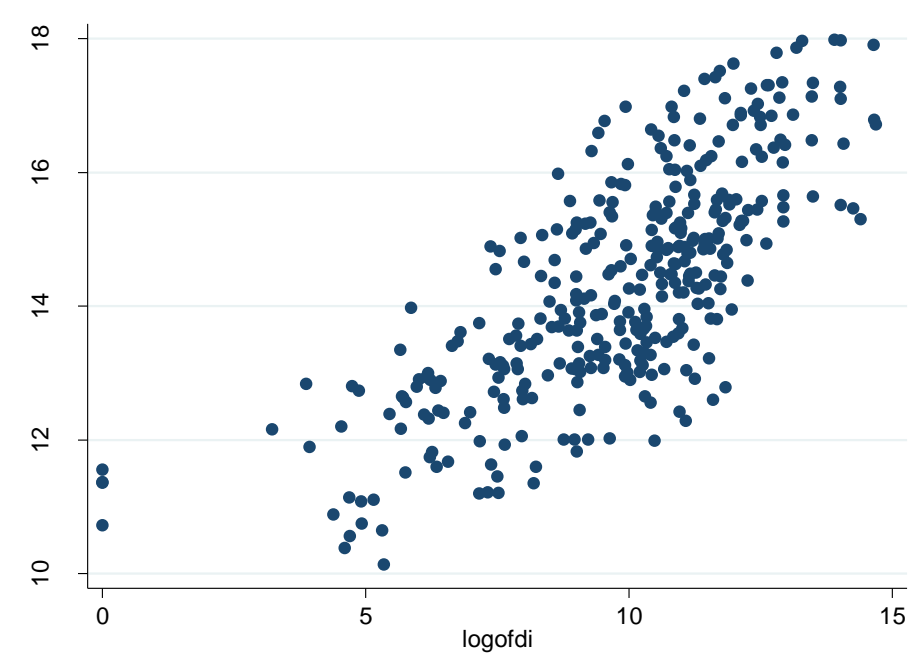

Figure 2. Scatter plot of China's export and OFDI 


\section{Empirical Analysis}

\subsection{Research Method}

The weakness of insufficient of sample of time series data and cross section data can be solved by the model with panel data, and through the combination of time series data and cross section data, the model with panel data can analyze heterogeneity between individuals. Thus, this paper tries to analysis the export structure effect of OFDI of Sichuan Province of China using panel data from 2004 to 2016 through STATA soft. In order to analyze Sichuan province's export structure effect, the region dummy variable will be added to the model.

This paper employ LLC method to test the stationary of panel data to avoid spurious regression. We will adjust the model if the panel data is non-stationary, otherwise we can estimate the model directly. After the stationary test, we estimated the model with fixed effect and random effect respectively. Furthermore, we made Hausman test to recognize whether the random effect or fixed effect model should be used in this paper. Then this paper adopted system GMM to make the regression because heteroscedasticity and serial correlation of the random error are allowed in the regression when system GMM is adopted. In order to find out the export structure effect, we made two regression for each method using ordinary export and export as the dependent variable respectively. If the influence coefficient of OFDI on ordinary export is greater than that on export, it indicates that OFDI can improve export structure.

\subsection{Stationary Test}

False regression may be made due to non-stationary of the panel data. This paper made the stationary test firstly. If variables have unit root, panel data needs to pass the co-integration test, otherwise, we will adjust the model. This paper made the test of stationary with the method of LLC(Levin-Lin-Chu) test, and P values of LLC test are shown in Table 2. All variables have no unit root and are stationary according to Table 2.

Table 2. Results of stationary test of all variables

\begin{tabular}{lllllll}
\hline \multicolumn{2}{c}{ variable } & logoexport & logexport & logofdi & L.logofdi & logpgdp \\
\hline \multirow{2}{*}{ LLC } & statistic & -7.7941 & -7.9040 & -3.2806 & -4.2944 & -13.5897 \\
& P value & 0.0000 & 0.0000 & 0.0005 & 0.0000 & 0.0000 \\
\hline
\end{tabular}

\subsection{Regression Analysis}

The results of regression by random effect and fixed effect and the result of hausman test indicate that fixed effect method is more suitable for this paper. Then, the model was estimated by the way of system GMM with first-lagged depended variable. Results of all regressions are shown in table 3.

Table 3. Regression result

\begin{tabular}{|c|c|c|c|c|c|c|}
\hline $\begin{array}{c}\text { explaining } \\
\text { variables }\end{array}$ & $\begin{array}{c}\text { Regress1 } \\
\text { logoexport } \\
\text { FE } \\
\end{array}$ & $\begin{array}{c}\text { Regress } 2 \\
\text { logexport } \\
\text { FE } \\
\end{array}$ & $\begin{array}{c}\text { Regress3 } \\
\text { logoexport } \\
\text { sysGMM } \\
\end{array}$ & $\begin{array}{l}\text { Regress4 } \\
\text { logexport } \\
\text { sysGMM } \\
\end{array}$ & $\begin{array}{c}\text { Regress5 } \\
\text { logoexport } \\
\text { OLS+dummy }\end{array}$ & $\begin{array}{c}\text { Regress6 } \\
\text { logexport } \\
\text { OLS+dummy }\end{array}$ \\
\hline L.logoexport & & & $\begin{array}{l}0.504 * * * \\
(0.0124)\end{array}$ & & & \\
\hline L.logexport & & & & $\begin{array}{l}0.647 * * * \\
(0.0102)\end{array}$ & & \\
\hline L.logofdi & $\begin{array}{l}0.0357^{*} \\
(0.0209)\end{array}$ & $\begin{array}{l}0.00651 \\
(0.0207)\end{array}$ & $\begin{array}{l}0.0588^{* * * *} \\
(0.00620)\end{array}$ & $\begin{array}{l}0.0297 * * * \\
(0.0102)\end{array}$ & $\begin{array}{l}0.0357 * \\
(0.0209)\end{array}$ & $\begin{array}{l}0.00651 \\
(0.0207)\end{array}$ \\
\hline logpgdp & $\begin{array}{l}0.748 * * * \\
(0.0711)\end{array}$ & $\begin{array}{l}0.917 * * * \\
(0.0703)\end{array}$ & $\begin{array}{l}0.167 * * * \\
(0.0340)\end{array}$ & $\begin{array}{l}0.138 * * * \\
(0.0403)\end{array}$ & $\begin{array}{l}0.748 * * * \\
(0.0711)\end{array}$ & $\begin{array}{l}0.917 * * * \\
(0.0703)\end{array}$ \\
\hline Constant & $\begin{array}{l}7.229 * * * \\
(0.425)\end{array}$ & $\begin{array}{l}6.630 * * * \\
(0.420)\end{array}$ & $\begin{array}{l}4.976 * * * \\
(0.0927)\end{array}$ & $\begin{array}{l}3.745 * * * \\
(0.133)\end{array}$ & $\begin{array}{l}6.981 * * * \\
(0.386)\end{array}$ & $\begin{array}{l}6.318 * * * \\
(0.382)\end{array}$ \\
\hline Sichuan & & & & & $\begin{array}{l}0.483^{* * * *} \\
(0.118)\end{array}$ & $\begin{array}{l}0.678 * * * \\
(0.116)\end{array}$ \\
\hline Observations & 324 & 324 & 324 & 324 & 324 & 324 \\
\hline R-squared & 0.741 & 0.777 & & & 0.967 & 0.974 \\
\hline Number of region & 27 & 27 & 27 & 27 & & \\
\hline
\end{tabular}

Robust standard errors in parentheses; *** $\mathrm{p}<0.01, * * \mathrm{p}<0.05, * \mathrm{p}<0.1$. 
According to table 3 , the coefficients of determination of all regressions are large, all coefficients are positive and most of coefficients are significant, which means that the models are suitable and close to practice. Results of regress 1 and regress 2 show that the coefficient of OFDI with ordinary export as dependent variable is larger than the coefficient of OFDI with export as dependent variable. That means China's OFDI has positive effect on export and ordinary export, and the promotion effect of China's OFDI to ordinary export is bigger than that of China's OFDI to export. Thus, we can come to the conclusion that China's OFDI can improve export structure since ordinary export can benefit trade, upgrade of technology and economy more than process export. We can come to the same conclusion according to the results of regress 3 and regress 4 with system GMM method which are more reliable because heteroscedasticity and serial correlation in the random error are taken into consideration. Furthermore, the coefficients of OFDI of regress 3 and regress 4 are more significant. Region dummy variable is added to the model in regress 5 and regress 6 , so that we can find out the export structure effect of Sichuan province's OFDI. The coefficient of Sichuan dummy variable in regress 5 is 0.483 which is smaller than that of in regress 6 . That means the promotion effect of Sichuan province's OFDI to ordinary export is smaller than that of Sichuan province's OFDI to export. So we can't come to the conclusion that Sichuan province's OFDI can improve export structure.

\section{Conclusion and Suggestion}

\subsection{Research Conclusion}

This paper made an export structure effect analysis of outward foreign direct investment of Sichuan Province of China using the method of OLS and GMM with the provincial panel data of ordinary export from 2004 to 2016. Through estimations, we can come to the conclusion that the export structure effect of OFDI is significant positive in China but not in Sichuan province. China's OFDI can promote export structure through increasing intermediate exports, raising technical level and fostering emerging industries. But this kind of effect is not big. This paper cannot find the evidence that Sichuan's OFDI can promote export structure. The reason of which may be that Sichuan's processing export developed very fast in the past decade since many processing enterprises in China's eastern region moved to sichuan.

This paper replenishes the study of China's trade effect of OFDI by expanding researches to the level of regions and taking account in the influence of Sichuan province. But this paper didn't go into more detail on the reason of Sichuan's OFDI didn't improve export structure. Finding and empirically verifying the reason could be an interesting research for all scholars.

\subsection{Suggestion}

From what has been discussed above, Sichuan province's OFDI didn't promote export structure in the past decade. One of the reasons for it may be the rapid growth of processing export. The type of OFDI may be another important reason. If OFDI couldn't drive equipment and intermediate exports and upgrade technology level, there will no promotion on export structure. So, Sichuan province needs to expand it's OFDI faster and focus on OFDI that can drive export and upgrade technology level.

\section{Acknowledgments}

A Project Supported by Scientific Research Fund of Sichuan Provincial Education Department (project number: 17SB0169).

\section{References}

Benwu, X. (2009). An Empirical Research on the Features of Host-country and China's Direct Investment Abroad. The Journal of Quantitative \& Technical Economics, 7, 33-46.

Chunping, Z. (2012). The Study on the Effects of China's OFDI on International Trade. The Journal of Quantitative \& Technical Economics, (6), 74-85.

Clausing, K. A. (2000). Does multinational activity displace trade? Economic Inquiry, 38(2), 190-205. https://doi.org/10.1111/j.1465-7295.2000.tb00013.x

Dunning, J. H. (1977). Trade, Location of Economic Activity and the Multinational Enterprise: A Search for an Eclectic Approach. In O. B. Hesselborn, \& P. M. Wijkman (Eds), The International Allocation of Economic Activity (pp. 395-418). Macmillan, London. https://doi.org/10.1007/978-1-349-03196-2_38

Guanhong, J., \& Dianchun, J. (2014). Outward Direct Investment and Export. Economic Research Journal, 5, $160-173$.

Helpman, E. (1984). A simple theory of international trade with multinational corporations. Journal of Political 
Economy, 92(3), 451-471. https://doi.org/10.1086/261236

Jarreau, J., \& Poncet, S. (2012). Export sophistication and economic growth: Evidence from China. Journal of Development Economics, 97(2), 281-292. https://doi.org/10.1016/j.jdeveco.2011.04.001

Jun-cong, C., \& Fan-hua, H. (2014). Foreign Direct Investment and Upgrading of Export Structure. Journal of International Trade, 3, 113-122

Lipsey, R. E. (2002). Home and Host Country Effects of FDI. NBER Working Paper 9293. National Bureau of Economic Research. https://doi.org/10.3386/w9293

Lipsey, R. E., \& Weiss, M. Y. (1984). Foreign production and exports of individual firms. Review of Economics \& Statistics, 66(2), 304-308. https://doi.org/10.2307/1925832

Marchant, M. A., Cornell, D. N., \& Koo, W. (2002). International trade and foreign direct investment: substitutes or complements?. Journal of Agricultural \& Applied Economics, 34(2), 289-302. https://doi.org/10.1017/S1074070800009044

Markusen, J. R. (1984). Multinationals, multi-plant economies, and the gains from trade. Journal of International Economics, 16(3-4), 205-226. https://doi.org/10.1016/S0022-1996(84)80001-X

Markusen, J. R., \& Venables, A. J. (1998). Multinational firms and the new trade theory. Journal of International Economics, 46(2), 183-203. https://doi.org/10.1016/S0022-1996(97)00052-4

Mundell, R. A. (1957). International trade and factor mobility. American Economic Review, 47(3), 321-335.

Xiaohui, W. (2017). A Provincial Panel Data Analysis on Export Effect of China's Inbound Tourism. International Journal of Business and Management, 12(6), 196-202. https://doi.org/10.5539/ijbm.v12n6p196

Xiaohui, W. (2017). Export Effect of China's Outward FDI: Provincial Panel Data Analysis. International Business Research, 10(7), 148-154. https://doi.org/10.5539/ibr.v10n7p148

Yuyu, C. (2012). Structure Effect of China's Outward Foreign Direct Investment on Trade. Statistical Research, $9,44-50$.

\section{Copyrights}

Copyright for this article is retained by the author(s), with first publication rights granted to the journal.

This is an open-access article distributed under the terms and conditions of the Creative Commons Attribution license (http://creativecommons.org/licenses/by/4.0/). 